\title{
Spatial and temporal variability of the pico- and nanophytoplankton and bacterioplankton in a deep Polynesian atoll lagoon
}

\author{
Y. Thomas $^{1,2, *}$, P. Garen ${ }^{2}$, C. Courties $^{3}$, L. Charpy ${ }^{4}$ \\ ${ }^{1}$ IFREMER, UMR 100, Presqu'île du Vivier, 29840 Argenton, France \\ ${ }^{2}$ IFREMER, COP, BP 7004, 98719 Taravao, Tahiti, French Polynesia \\ ${ }^{3}$ UPMC Univ. Paris 06, and CNRS, UMS 2348, MBCE, Observatoire Océanologique, 66651 Banyuls-sur-mer, France \\ ${ }^{4}$ IRD, CNRS, and Univ. Méditerranée, UMR UPB, BP 529, 98713 Papeete, Tahiti, French Polynesia
}

\begin{abstract}
Spatial and temporal scales of variability in phyto- and bacterioplankton abundance were investigated in a deep atoll lagoon (Ahe, French Polynesia). Ahe Lagoon showed a classical phytoplankton composition, but its picophytoplankton (Prochlorococcus, Synechococcus and picoeukaryotes) concentrations are higher than the mean for Polynesian atoll lagoons. Phyto- and bacterioplankton descriptors were highly variable, with mean CVs of $>20 \%$ in most cases: daynight, day-to-day, vertical, lagoonal and seasonal. Phytoplankton biomass, which was estimated by in vivo fluorescence, was higher in the deep layer than in the upper layer. This pattern was detected on a day-night scale, showing transitory vertical gradients, and through long-term events that were recorded during day-to-day measurements, especially during low wind conditions. The main factors potentially driving this vertical structure of the phytoplankton appeared to be photoinhibition in upper layers and a bottom effect providing more favourable nutrient conditions in deeper layers. Day-to-day fluctuation was the major source of temporal variation and appeared to be highly driven by vertical patterns and mixing events showing phytoplankton supply from deep layers. At the lagoon scale, the picophytoplankton exhibited a patchy structure that is closely linked to the geomorphology of the rim, lagoon depth and proximity of the pass. Stations close to the pass were characterized by consistently lower Synechococcus and picoeukaryote concentrations. Lastly, warm periods showed higher Synechococcus, nanophytoplankton and bacterial concentrations. Prochlorococcus and picoeukaryotes showed no seasonal trend, but had an annual variability that could be related to variations in exchanges between the lagoon and the ocean.
\end{abstract}

KEY WORDS: Flow cytometry · Picophytoplankton · Nanophytoplankton · Bacterioplankton • Vertical distribution · Day-to-day dynamics · Large-scale heterogeneity · Deep atoll lagoon . French Polynesia

Resale or republication not permitted without written consent of the publisher

\section{INTRODUCTION}

Atoll lagoons are systems that show distinct characteristics compared with the surrounding oceanic waters, with higher abundances of autotrophic picoand nanoplankton and elevated bacterial biomass and activity (Le Borgne et al. 1989, Torréton \& Dufour 1996, Charpy et al. 1997, Charpy \& Blanchot 1998, González et al. 1998). Lagoon waters are usually described as very stable and homogeneous ecosystems (Torréton \& Dufour 1996, Delesalle et al. 2001, Ferrier-Pagès \& Furla 2001). Their biological functioning is mostly driven by hydrodynamics, particularly water residence time (Delesalle \& Sournia 1992, Charpy et al. 1997, Torréton et al. 2007), which is closely linked to atoll geomorphology and water exchanges with the open ocean, via the reef rims (Sournia \& Ricard 1976, Charpy \& Blanchot 1998, Andréfouët et al. 2001). 
Microbes play major roles in pelagic food webs and biogeochemical cycles (Pomeroy 1974, Cho \& Azam 1990). They respond quickly to temporal and spatial variations in their environment; the scale and source of such variability are likely to play a significant role in the long-term equilibrium of an ecosystem (Haury et al. 1978, González et al. 1998). Therefore, despite the environmental homogeneity commonly assumed in atoll lagoon waters, numerous studies highlight transitory variations in hydrobiological parameters at small scales, such as in day-to-day, diel or vertical distributions of temperature, salinity, chl a or microbial community abundance (Sournia \& Ricard 1976, Moriarty et al. 1985, Charpy-Roubaud et al. 1988, Charpy \& Blanchot 1998, González et al. 1998, Buestel \& Pouvreau 2000). However, most of these studies were done in shallow lagoons, which were usually considered as well mixed and thus homogeneous (Torréton \& Dufour 1996, González et al. 1998, Charpy \& Blanchot 1999). Our present knowledge concerning deep atoll lagoons is scarce. In this study, we hypothesize that hydrodynamics, which is partially dependent on deep atoll morphology, drives biological functioning, making this specific ecosystem a suitable habitat for microbial communities (Atkinson et al. 1981).

The main objectives of this study were thus to determine the spatio-temporal scales of variation in autotrophic phytoplankton and bacteria in a deep atoll lagoon (Ahe, French Polynesia), and to develop conceivable scenarios to understand this variability. Our study focused on the phytoplanktonic and bacterial compartments, from integrative descriptors such as in vivo phytoplanktonic concentration and size-fractionated extracted chl $a$, to pico-, nano- and bacterioplankton identification and quantification by flow cytometry. We developed a sampling strategy that allowed us to cover a wide range of scales so as to measure (1) verti- cal profiles, (2) day-to-day temporal variability, (3) lagoon-scale patterns, and (4) seasonal variability.

\section{MATERIALS AND METHODS}

Sampling site. Ahe Atoll is located in the northwestern part of the French Polynesian Tuamotu Archipelago at $500 \mathrm{~km}$ northeast of Tahiti Island (Fig. 1). Ahe Lagoon measures $145 \mathrm{~km}^{2}$ and has a mean depth close to $50 \mathrm{~m}$. Ahe is defined as a semi-enclosed atoll. One active pass is located in the western part of the lagoon and several reef-flat spillways (<50 cm depth) are distributed along the reef rim, mainly in the southern and western parts of the lagoon. The average water residence time (ratio of lagoon volume to average water input rate) is estimated at 34 d (Pagès et al. 2001).

Environmental parameters. Meteorological data (wind direction and velocity, and rainfall) were obtained from the Takaroa Atoll meteorological station, which is located $120 \mathrm{~km}$ east of Ahe (14 28' 57" S, $\left.145^{\circ} 3^{\prime} 4^{\prime \prime} \mathrm{W}\right)$. For the $24 \mathrm{~h}$ cycles (see below), wind direction and velocity were recorded in the field with a mobile anemometer. Since no tidal records were made, tidal cycles were simulated by decomposition of tide harmonics obtained from another study performed in the Ahe Lagoon (R. Le Gendre pers. comm.), giving tidal amplitude (m) in the lagoon with a 15 min time step.

Vertical profiles of salinity (practical salinity scale), temperature $\left({ }^{\circ} \mathrm{C}\right)$, in vivo $\mathrm{chl} \mathrm{a}\left(\mu \mathrm{g} \mathrm{l}^{-1}\right)$ and PAR (photo-

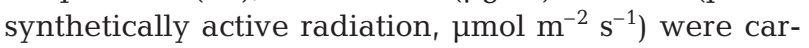
ried out with a multiparameter probe (SBE S19Plus, Sea-Bird Electronics). To extract the contribution of pico- and nanophytoplankton to chl a concentration, the biomass of size-fractionated chl $a<2 \mu \mathrm{m}$ and $>2 \mu \mathrm{m}$ were measured. Total chl a concentration was assessed using Whatman GF/F (0.7 $\mu \mathrm{m}$ pore size) filters and chl
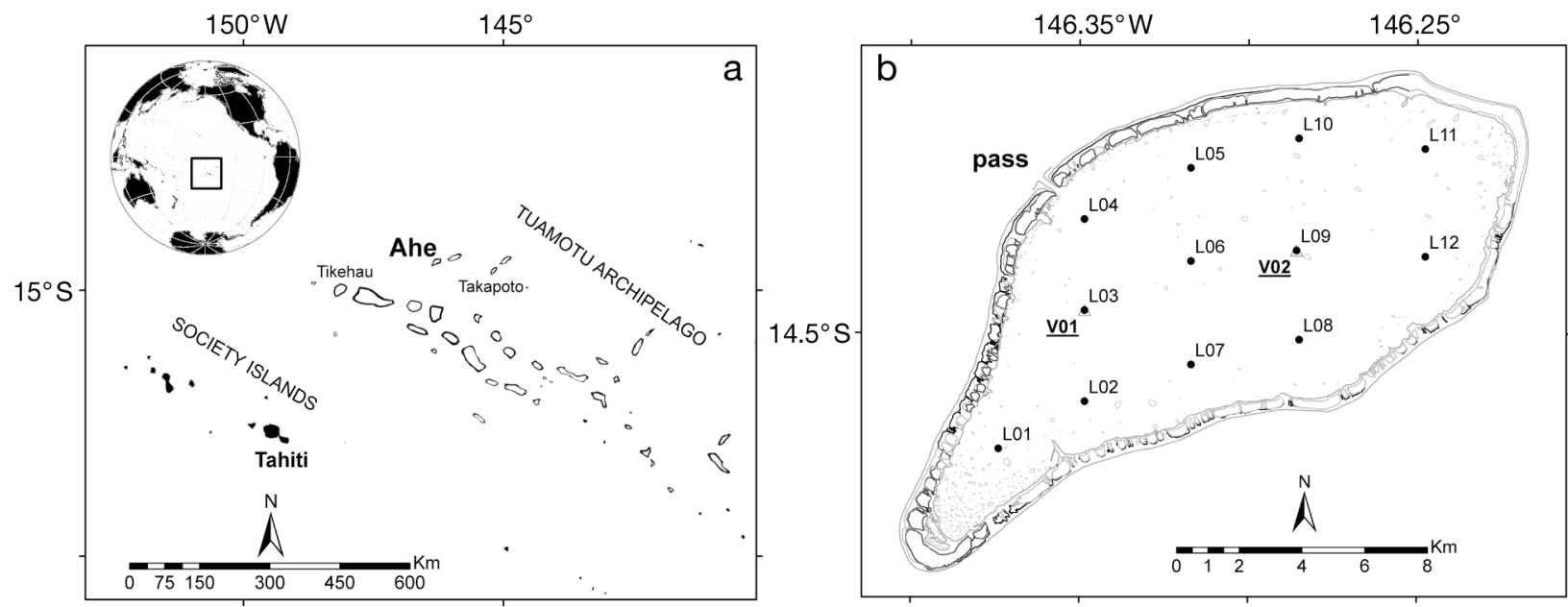

Fig. 1. (a) Location of Ahe Lagoon. (b) Positions of the sampling stations in the lagoon 
a $>2 \mu \mathrm{m}$ using Millipore $(2 \mu \mathrm{m}$ pore size) filters. The concentration of chl $a<2 \mu \mathrm{m}$ was calculated as the difference between total chl $a$ and chl $a>2 \mu \mathrm{m}$. Sea water samples (0.3 l) were filtered, and the filters were rinsed with deionized water and stored at $-20^{\circ} \mathrm{C}$. Chlorophyll collected on the filters was extracted in $96 \%$ ethanol as recommended by Wasmund et al. (2006). Extracts were processed by fluorimetry (Turner 10-AU-005-CE, Turner Designs) according to Yentsch (1963).

Flow cytometry (FCM) analysis. Samples $(1.5 \mathrm{ml})$ were preserved with $2 \%$ formol (final concentration) and stored at $-80^{\circ} \mathrm{C}$ after freezing in liquid nitrogen, allowing delayed FCM analysis (Troussellier et al. 1995). After thawing at room temperature, samples were analysed using a FACSCan flow cytometer (BDBiosciences) that was equipped with an air-cooled argon laser (488 nm, $15 \mathrm{~mW}$ ). Phytoplanktonic cells were discriminated and enumerated according to their right-angle light scatter properties (roughly related to cell size) and the orange (560-620 nm) and red (>670 nm) fluorescence from their phycoerythrin and chlorophyll pigments, respectively. SYBR Green I (Molecular Probes) was used to stain bacterial populations, which were discriminated and enumerated by their nucleic acid contents according to their rightangle light scatter and green fluorescence (Marie et al. 2000). Data acquisition was performed using CellQuest software (BD-Biosciences). Fluorescent $1.002 \mu \mathrm{m}$ beads (Polysciences) were systematically added to each sample to normalize cell fluorescence and light scatter emissions, thus allowing comparison of results. To estimate cell concentrations, the exact volume of water analysed was determined by measuring the sample volume before and after analysis.

Sampling design. For chl a extraction and flow cytometry analysis, water was sampled by pumping at a flow rate of $5 \mathrm{~m}^{3} \mathrm{~h}^{-1}$. A pipe of $32 \mathrm{~mm}$ diameter was connected to the pump and immersed at the required depth.
Vertical profiles: These were were studied during day-night cycles. Two deep stations (V01 and V02, $50 \mathrm{~m}$ deep) (Fig. 1) were sampled at intervals of $4 \mathrm{~h}$ over $24 \mathrm{~h}$ cycles. A vertical profile was obtained every $4 \mathrm{~h}$ using a multiparameter probe, and water samples were taken at 5, 15, 25, 35 and $45 \mathrm{~m}$ depth for chl a extraction and flow cytometry analysis. The 2 stations were sampled successively at an interval of $24 \mathrm{~h}$, and 3 surveys of these nycthemeral cycles were carried out in April 2007, July 2007 and February 2008.

In parallel, day-to-day vertical profiles were obtained with the multiparameter probe in 12 stations (L01 to L12) distributed across the lagoon (Fig. 1). Vertical profiles were obtained in the morning at each station from L12 to L01. Four surveys with day-to-day profiles recording were carried out (April-May 2007, July-August 2007, November 2007, and FebruaryMarch 2008). For technical reasons, day-to-day samplings were of different durations: 29, 15, 20 and $29 \mathrm{~d}$ during the 4 survey periods, respectively, and no $24 \mathrm{~h}$ cycles were studied in November (Table 1).

Day-to-day temporal variability: This was studied through daily sampling, results of which were averaged over the 12 'lagoon' stations. In addition to the day-to-day profiles obtained with the multiparameter probe, 1 water sample was obtained at $5 \mathrm{~m}$ depth at the 12 stations every $2 \mathrm{~d}$ for size-fractionated chl a analysis, and another every $4 \mathrm{~d}$ for flow cytometry analysis. A summary of the sampling strategy is given in Table 1.

Data analysis and statistics. For vertical profile analysis, multiparameter probe profiles were averaged for each $10 \mathrm{~m}$ layer (i.e. 0-10, 10-20, 20-30, 30-40, 40-50 m). Mean light profiles were calculated by dividing the irradiance at each metre of depth by the irradiance measured at $1 \mathrm{~m}$ depth. Lagoon-scale patterns were extracted from 'lagoon' station surveys by comparing the averaged day-to-day results for each station. Finally, seasonal variability was extracted

Table 1. Summary of the sampling strategy. MPP: multiparameter probe, FCM: flow cytometry, chl a: size-fractionated chl a extraction

\begin{tabular}{|c|c|c|c|c|c|c|c|}
\hline \multirow[t]{2}{*}{ Date } & \multirow{2}{*}{ Study type } & \multirow[t]{2}{*}{ Stations } & \multirow{2}{*}{ Period } & \multicolumn{3}{|c|}{ Sampling frequency } & \multirow{2}{*}{ Depth (m) } \\
\hline & & & & MPP & FCM & Chl a & \\
\hline \multirow[t]{2}{*}{ Apr-May 07} & Day-night & V01, V02 & $24 \mathrm{~h}$ & $4 \mathrm{~h}$ & $4 \mathrm{~h}$ & $4 \mathrm{~h}$ & \multirow{2}{*}{$\begin{array}{c}5,15,25,35,45 \\
5^{\mathrm{a}}\end{array}$} \\
\hline & Day-to-day & L01 - L12 & $29 \mathrm{~d}$ & $1 \mathrm{~d}$ & $4 \mathrm{~d}$ & $2 \mathrm{~d}$ & \\
\hline \multirow[t]{2}{*}{ Jul-Aug 07} & Day-night & V01, V02 & $24 \mathrm{~h}$ & $4 \mathrm{~h}$ & $4 \mathrm{~h}$ & $4 \mathrm{~h}$ & \multirow{2}{*}{$\begin{array}{c}5,15,25,35,45 \\
5^{\mathrm{a}}\end{array}$} \\
\hline & Day-to-day & L01 - L12 & $15 \mathrm{~d}$ & $1 \mathrm{~d}$ & $4 \mathrm{~d}$ & $2 \mathrm{~d}$ & \\
\hline \multirow[t]{2}{*}{ Nov 07} & Day-night & - & - & - & - & - & \multirow{4}{*}{$\begin{array}{c}- \\
5^{\mathrm{a}} \\
5,15,25,35,45 \\
5^{\mathrm{a}}\end{array}$} \\
\hline & Day-to-day & L01 - L12 & $20 \mathrm{~d}$ & $1 \mathrm{~d}$ & $4 \mathrm{~d}$ & $2 \mathrm{~d}$ & \\
\hline \multirow[t]{2}{*}{ Feb-Mar 08} & Day-night & V01, V02 & $24 \mathrm{~h}$ & $4 \mathrm{~h}$ & $4 \mathrm{~h}$ & $4 \mathrm{~h}$ & \\
\hline & Day-to-day & L01 - L12 & $29 \mathrm{~d}$ & $1 \mathrm{~d}$ & $4 \mathrm{~d}$ & $2 \mathrm{~d}$ & \\
\hline
\end{tabular}


from the comparison of the averages of data from day-to-day sampling performed during the 4 surveys: April-May, July-August, November and Feb-March.

The coefficient of variation (CV) (=SD/MV, where MV is the mean value) was calculated for each parameter to quantify the degree of variability at different scales. To represent and test spatial heterogeneity, mean data were standardized using the standard score $z$ calculation: $z=$ $(\mathrm{V}-\mathrm{MV}) / \mathrm{SD}$, where $\mathrm{V}$ is the data value. After arcsine transformation of CVs, ANOVA was used to test (1) differences in CVs among scales, (2) the lagoonal heterogeneity of $z$ values, and (3) the seasonal effect on mean values. A post hoc Tukey's pairwise multiple comparison test was performed when significant differences were detected. Finally, Pearson correlation coefficients were calculated to test the relation between environmental factors (i.e. wind velocity, tidal amplitude and light intensity) and plankton abundance data from $24 \mathrm{~h}$ cycles.

\section{RESULTS}

\section{Flow cytometry identification}

Five phytoplankton populations were identified according to their normalized light scatter $\left(\mathrm{SSC} \mu \mathrm{m}^{-1}\right)$ and red fluorescence (FLR $\mu^{-1}$ ) properties. Two populations belonged to the picophytoplanktonic prokaryotes (Prochlorococcus [Prochl] and Synechococcus [Syn]), and one to the picoeukaryotic population (Peuk). Large eukaryotes were represented by 2 cell types (N1 \& N2) that were characterized by increasing SSC and FLR properties. The averaged normalized $\mathrm{SSC}$ ratio between $\mathrm{N} 2$ and N1 was 3.7. Due to their low concentrations, the abundances of these 2 cell types were pooled and are considered as a single nanophytoplankton population (Nan) in this paper.

For heterotrophic bacteria, 2 main populations were enumerated: those with a high apparent nucleic acid content (HNA) and those showing a low apparent nucleic acid content (LNA).

\section{Vertical profiles}

Day-night cycles

Wind velocity (WV) was measured during 3 day-night cycles: April 2007, July-August 2007 and February 2008, at the V01 and V02 stations (Fig. 2, right axes). During the first 2 surveys (Fig. 2a,b), wind velocity was significantly higher at Stn V02 than at Stn V01 ( $\mathrm{p}<0.0001$ ). In February, low wind velocities were recorded (Fig. 2c), with no significant difference ( $p>$ 0.05) between stations.
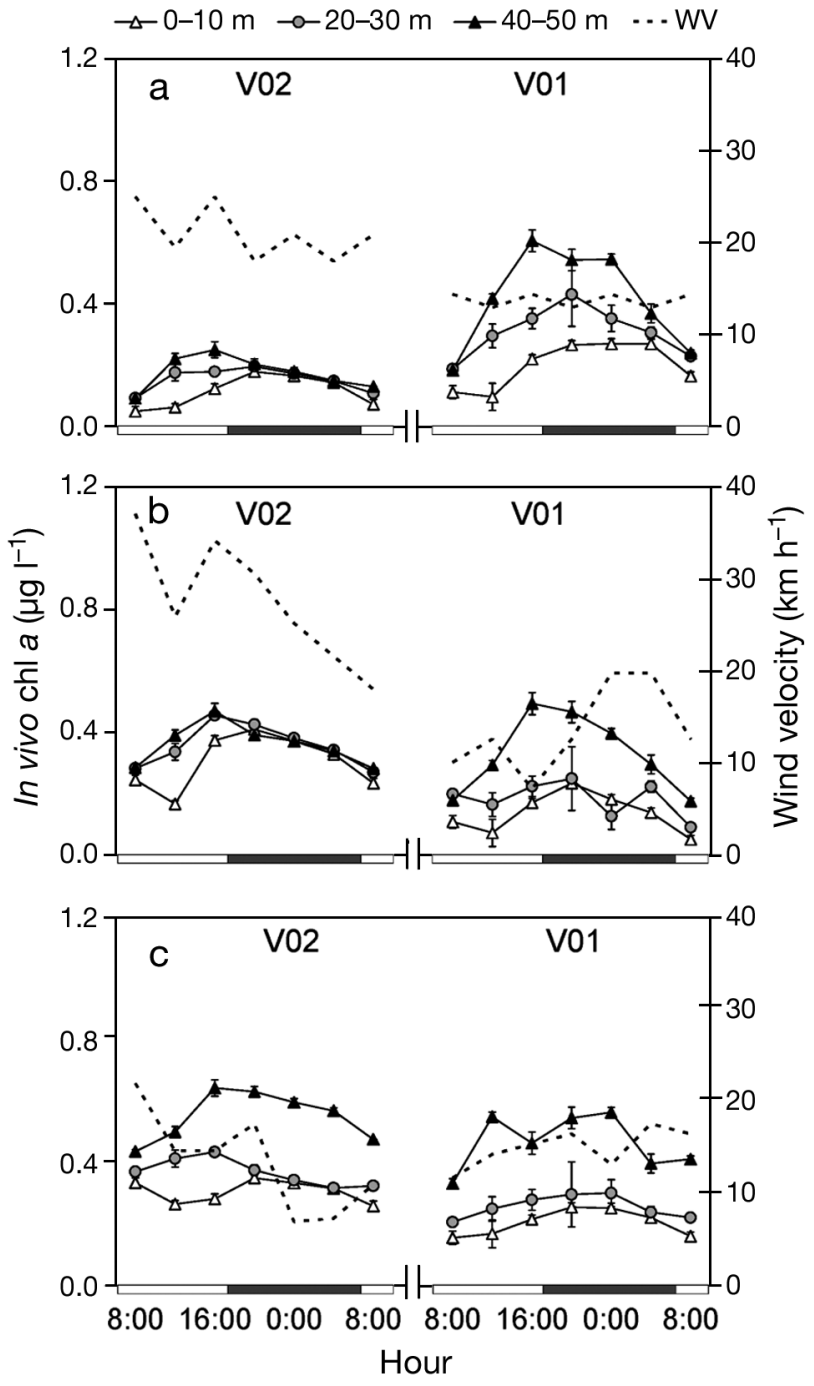

Fig. 2. Day-night variation in average in vivo chl a at 3 depth layers $(0-10,20-30$ and $40-50 \mathrm{~m})$ and wind velocity (WV, right axis) measured in (a) April 2007, (b) July 2007 and (c) February 2008 at Stns V01 and V02. Black sectors on the $X$-axis represent night

In vivo chl a concentrations measured during the 3 day-night cycles (Fig. 2) and averaged at each of the 3 layers (0-10, 20-30 and 40-50 m) showed an increase, with a mean multiplication factor of 1.8 from 08:00 to 16:00 $\mathrm{h}$, followed by a decrease during the night. Increases from $08: 00$ to $16: 00 \mathrm{~h}$ were significantly lower in the first 2 layers, from 0 to $30 \mathrm{~m}$ depth (ANOVA on slope; Tukey's test, p < 0.05), and a midday decrease in in vivo fluorescence was shown in the first $10 \mathrm{~m}$ at the V02 station during the 2 last surveys (Fig. 2b,c). These diurnal cycles showed an increasing chl a concentration toward the bottom. The mean ratio calculated between the upper $10 \mathrm{~m}$ and the deeper 10 $\mathrm{m}$ layers was 2 , reaching 4.3 at $12: 00 \mathrm{~h}$ during the first cycle at V01 (Fig. 2a). In April and July, the in vivo chl 
$a$ vertical gradient was smoother at V02, and total mixing occurred after 16:00 h (Fig. 2a,b). In the February day-night cycles, the chl a vertical gradients at the 2 stations were similar and were maintained through the sampling cycle (Fig. 2c).

FCM abundances of the selected phytoplankton classes (Prochl, Syn, Peuk and Nan) and HNA and LNA bacteria during the first two $24 \mathrm{~h}$ cycles at 5,25 and $45 \mathrm{~m}$ are given in Fig. 3. Increases in the abundances of the Peuk, Prochl and Syn communities occurred mainly during the day, after 12:00 h. Syn and Prochl showed a vertical gradient at Stn V01, with higher abundances in the bottom layer. As with in vivo chl a during the same surveys, microbial community abundances exhibited lower vertical variation at Stn V02 than at Stn V01. Nan showed no temporal or vertical patterns. HNA and LNA bacterial abundances were highly variable, with no clear vertical patterns, and only showed an increase during the cycle at Stn V01, which was followed by a strong decrease until 20:00 h.

As illustrated by the negative correlation of wind velocity with the CVs calculated on vertical profiles in chl a, Peuk, Prochl, and Syn concentrations (Table 2), differences measured in the vertical profiles and observed on the day-night scale were maintained during low wind periods.
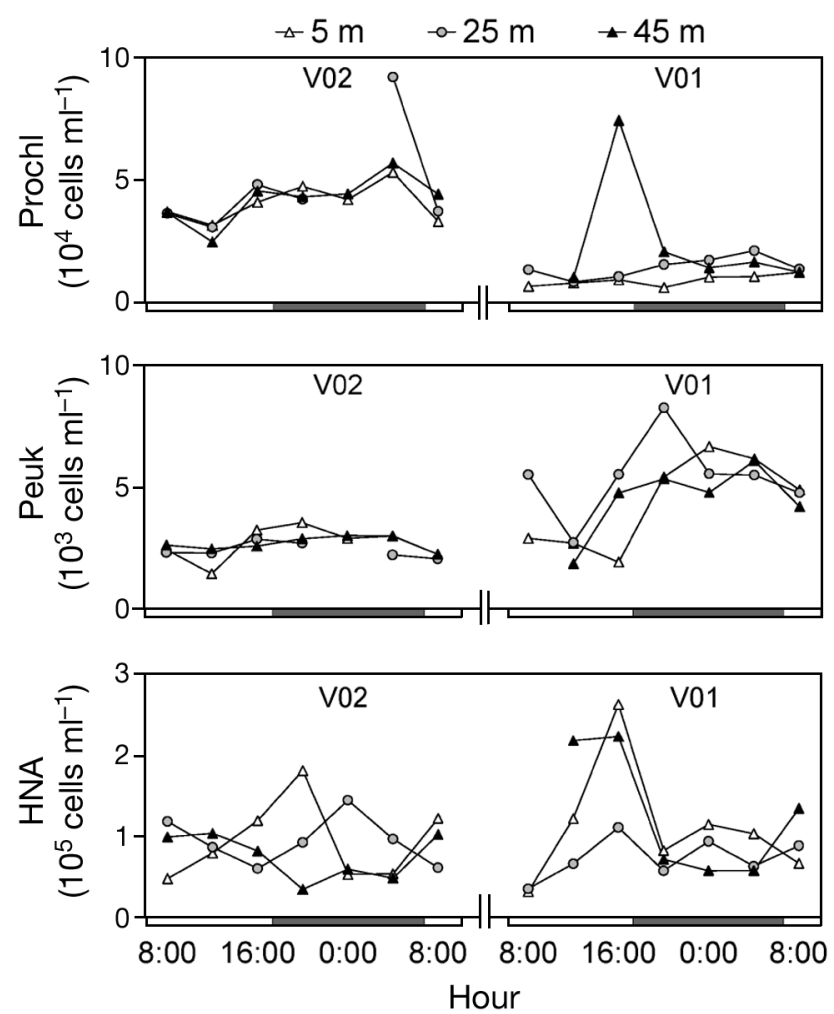

Table 2. Pearson correlation among environmental parameters and the pico- and nanophytoplankton, bacterioplankton and in vivo chl a concentrations according to day-night cycles and vertical profiles. WV: wind velocity; TA: tidal amplitude; PAR: photosynthetically active radiation (for data in bold, $\mathrm{p}<0.05)$

\begin{tabular}{|crrr}
\hline Variable Label & $\begin{array}{c}\mathrm{WV} \\
\left(\mathrm{km} \mathrm{h}^{-1}\right)\end{array}$ & $\begin{array}{r}\mathrm{TA} \\
(\mathrm{m})\end{array}$ & $\begin{array}{r}\text { PAR }(\mu \mathrm{mo} \\
\left.\mathrm{m}^{-2} \mathrm{~s}^{-1}\right)\end{array}$ \\
\hline $\begin{array}{c}\text { Day-night variation } \\
\text { a }\end{array}$ & & & \\
In vivo chl a & 0.04 & 0.11 & $\mathbf{- 0 . 4 9}$ \\
Nanophytoplankton & 0.04 & -0.21 & 0.22 \\
Picoeukaryotes & -0.03 & 0.19 & $\mathbf{- 0 . 5 4}$ \\
Prochlorococcus & 0.00 & 0.03 & $\mathbf{- 0 . 4 9}$ \\
Synechococcus & 0.11 & 0.23 & $\mathbf{- 0 . 5 3}$ \\
HNA bacteria & 0.09 & 0.01 & $\mathbf{0 . 3 2}$ \\
LNA bacteria & 0.11 & -0.09 & 0.16 \\
In vivo chl a & & & \\
Nanophytoplankton & -0.11 & -0.11 & 0.01 \\
Picoeukaryotes & $\mathbf{- 0 . 4 6}$ & 0.00 & 0.04 \\
Prochlorococcus & $\mathbf{- 0 . 4 0}$ & -0.06 & -0.14 \\
Synechococcus & $\mathbf{- 0 . 4 2}$ & -0.07 & 0.00 \\
HNA bacteria & -0.23 & -0.10 & 0.21 \\
LNA bacteria & -0.21 & -0.10 & 0.15
\end{tabular}

${ }^{\text {a}}$ Standard score $z$ of the concentration averaged over the water column $(6$ cycles $\times 7 \mathrm{~h} ; \mathrm{n}=42)$

${ }^{\mathrm{b}} \mathrm{CV}$ of the vertical profile of concentrations calculated at 5 depths $\mathrm{h}^{-1}(6$ cycles $\times 7 \mathrm{~h} ; \mathrm{n}=42)$
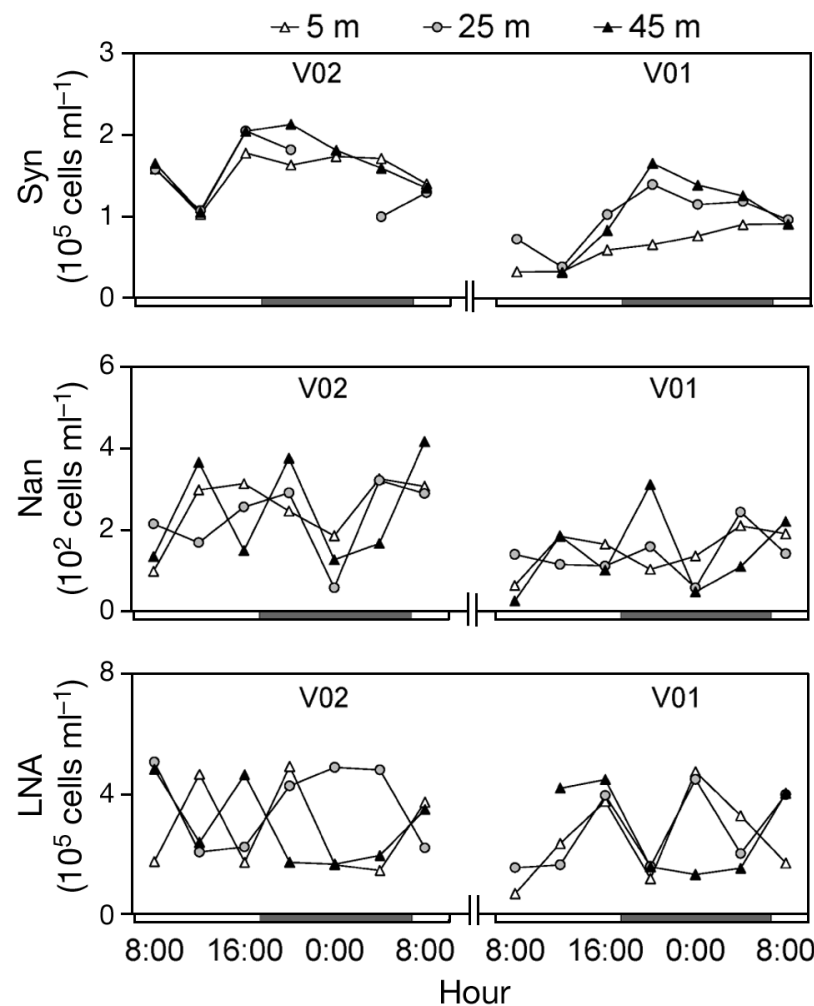

Fig. 3. Day-night variation in the abundances of Prochlorococcus (Prochl), Synechococcus (Syn), picoeukaryotes (Peuk), nanophytoplankton (Nan), high-nucleic acid (HNA) and low-nucleic acid (LNA) bacteria at 3 depths (5, 25 and 45 m) in February 2008 at Stns V01 and V02. Black sectors on the $x$-axis represent night. Prochl, Syn, and Peuk data are lacking at Stn V02 at 00:00 h 
Day-to-day vertical profiles

Averaging all light profiles, the percentages of the $1 \mathrm{~m}$ depth light energy reaching 10, 20, 30, 40 and 50 m were $54,20,16,8$ and $4 \%$, respectively (data not shown). For wind velocity during the 4 surveys (Fig. 4a) made in April-May, August, November and February-March, variations recorded on the day-today scale gave mean CVs of $30,33,42$ and $23 \%$, respectively. Water temperature difference on the vertical profiles occurred during low wind periods, reaching $0.52^{\circ} \mathrm{C}$ between 5 and $45 \mathrm{~m}$ in February (Fig. 4b). Salinity difference on vertical profiles was low $(<0.1)$ and mostly recorded during the first survey (Fig. 4c). Variations were mainly recorded in the upper $10 \mathrm{~m}$ layer and were linked to rainfall events (Pearson correlation: -0.21, p < 0.05). Chl a concentrations exhibited a vertical gradient in every season, with highest concentrations toward the bottom (Fig. $4 \mathrm{~d}$ ) and a mean CV calculated among the different layers of $38 \%$. An important event occurred in May, between Day 10 and Day 20, resulting in maximal in vivo chl a concentration at depths of over $30 \mathrm{~m}$. Concentrations increased from the surface to the bottom, with an overall mean difference factor of 2.7, which reached a maximum of 5.9 in February. Mixing events, which were characterized by an increase in surface chl a concentration and a decrease at the bottom (e.g. after Day 20 during the third and fourth surveys), indicated a supply from the deep layers. Chl a vertical gradients were related to wind speed: chl a concentration variability on vertical profiles calculated from day-to-day measurements showed a significant negative relation with wind velocity (linear regression: $\mathrm{CV}_{\text {in vivo chl } a}=-1.48 \mathrm{WV}+68, \mathrm{R}^{2}=0.15, \mathrm{p}$ $<0.05, \mathrm{n}=1079$ ).
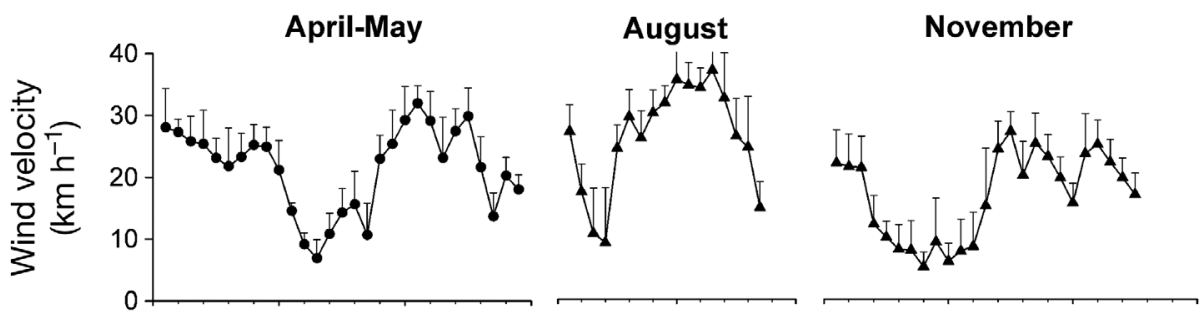

\section{February-March}
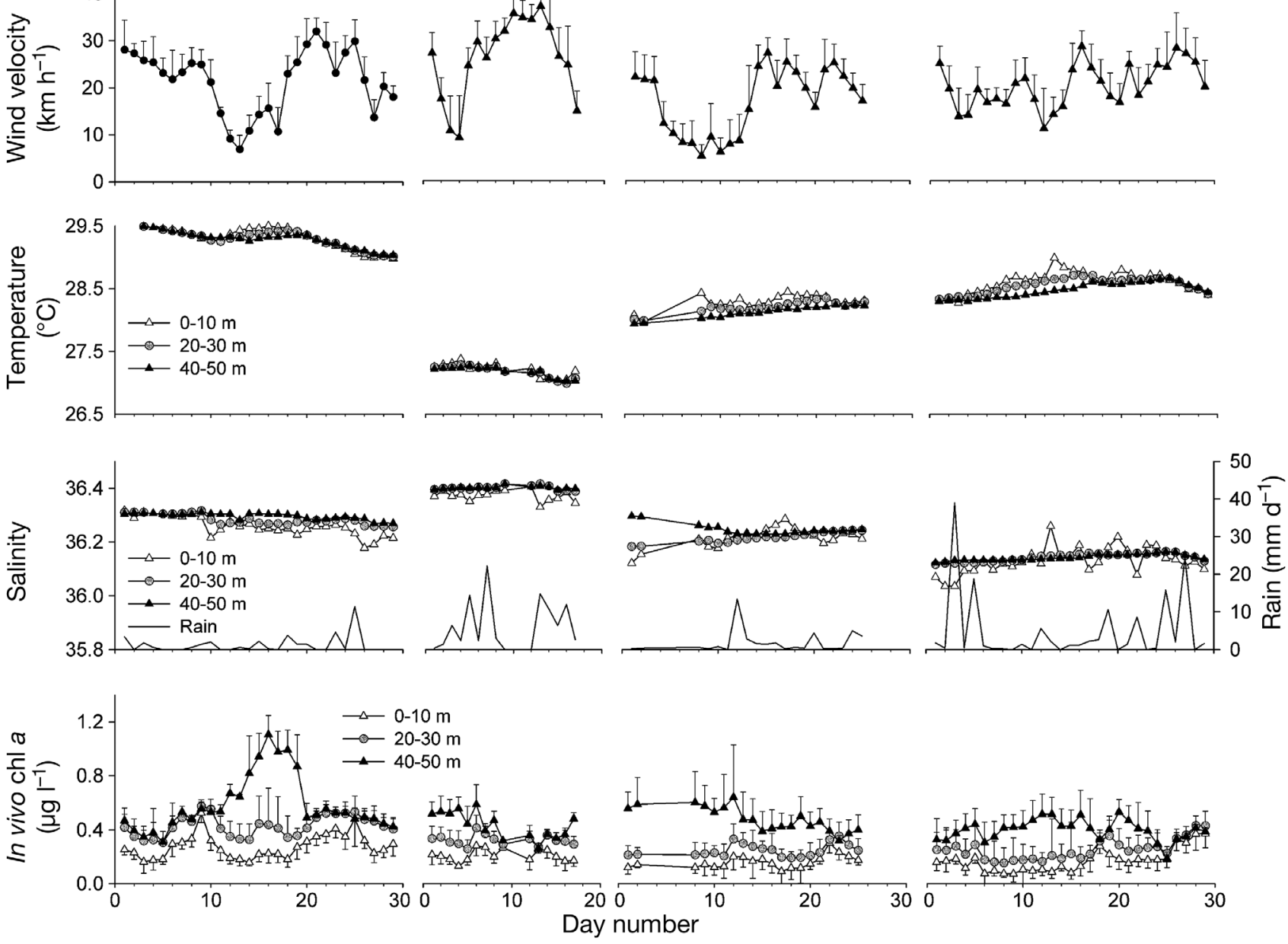

Fig. 4. Day-to-day variation in (a) wind velocity, (b) water temperature, (c) salinity, and (d) average in vivo chl a at 3 depth layers (0-10, 20-30 and 40-50 m) during the 4 surveys (April-May 2007, August 2007, November 2007 and February-March 2008). Data are means $( \pm \mathrm{SD})$ of measurements at the 12 lagoon stations 


\section{Day-to-day temporal variability}

The abundance of whole microbial communities showed high day-to-day variations in mean intra-survey $\mathrm{CV}$ of over $20 \%$ (Table 3 ). Chl a $>2 \mu \mathrm{m}$, nanophytoplankton and HNA bacteria showed the highest CVs of 47,46 and $42 \%$, respectively. Peuk showed the lowest day-to-day variation, with a mean CV of $27 \%$.

Phytoplankton concentrations ranged from 0 to $2 \mu \mathrm{g}$ $\mathrm{l}^{-1} \mathrm{chl}$ a measured in vivo, with marked differences according to depth: the mean intra-survey day-to-day CVs calculated for the whole water column and by $10 \mathrm{~m}$ depth layers were 25 and $32 \%$, respectively (Table 3). Larger variations were recorded at depths of over $30 \mathrm{~m}$, mainly during the April-May survey (see Fig. 4d).

Fractionated chl a measured at $5 \mathrm{~m}$ depth (Fig. 5a) ranged from 0.01 to $0.52 \mu \mathrm{g}^{-1}$ for chl $\mathrm{a}<2 \mu \mathrm{m}$ (left axis) and 0 to $0.24 \mu \mathrm{g} \mathrm{l}^{-1}$ for chl $a>2 \mu \mathrm{m}$ (right axis). The variations in the 2 fractions were different during the April-May survey: the first increase, which was observed at $5 \mathrm{~m}$ depth before Day 10, was mostly made up of picophytoplankton; the second increase, which was observed after Day 15, was made up of both picoand nanophytoplankton.

Nan ranged from $0.1 \times 10^{3}$ to $2.9 \times 10^{3} \mathrm{ml}^{-1}$ (Fig. $5 \mathrm{~b}$, left axis) and contributed mostly to the second abundance increase observed in April-May, after Day 15. Peuk varied between $0.8 \times 10^{3}$ and $13.5 \times 10^{3} \mathrm{ml}^{-1}$, and seemed to contribute to all the abundance increases observed during the 4 surveys (Fig. 5b, left axis). The picophytoplanktonic prokaryotes Prochl and Syn ranged from $12 \times 10^{3}$ to $251 \times 10^{3} \mathrm{ml}^{-1}$ and from $22 \times 10^{3}$ to $276 \times 10^{3} \mathrm{ml}^{-1}$, respectively, and varied mainly during the first survey in April-May, with an increasing contribution of the Prochl community to the second adundance increase, after Day 15 (Fig. 5b, right axis). HNA and LNA bacteria ranged from $0.3 \times 10^{5}$ to $20.3 \times 10^{5} \mathrm{ml}^{-1}$ and from $1.2 \times 10^{5}$ to $14.3 \times 10^{5} \mathrm{ml}^{-1}$, respectively. The 2 communities showed the same day-to-day trend (Pearson correlation: 0.82, p < 0.0001) with a noticeable abundance increase after Day 15 during the April-May survey (Fig. 4c).

\section{Lagoon-scale patterns}

Results evaluated at the lagoon scale are shown in Fig. 6. There was an east-west gradient in temperature, with significantly higher temperatures in the west than in the east $(p<0.05)$. Salinity appeared to be homogeneous in the lagoon, with only the L01 station showing significantly lower values $(p<0.05)$. The mean inter-station CVs exceeded $20 \%$ for the phyto- and bacterioplankton descriptors (Table 3). General patterns showed a patchy structure, with higher chl $a<2 \mu \mathrm{m}$, chl $a>2 \mu \mathrm{m}$, in vivo chl $a$, Peuk and Syn concentrations in the west (i.e. Stn L01) and also in the east (i.e. Stns L10, L11, L12) for chl a $>2 \mu \mathrm{m}$, Peuk and Syn. For the same 5 parameters, Stns L03 and L04 showed the lowest concentrations. Prochl exhibited a west-east gradient, with increasing concentrations eastward. Finally, no significant spatial differences were found for Nan, HNA or LNA $(\mathrm{p}>0.05)$.

Table 3. CV (\%) of the meteorological, hydrological and hydrobiological parameters at the spatial and temporal scales studied. Different letters indicate significant CV differences between scales (Tukey's test, $p<0.05$ ). Since there was only $1 \mathrm{df}$ for the seasonal scale, season was excluded from the test. HNA: high-nucleic acid, LNA: low-nucleic acid

\begin{tabular}{|c|c|c|c|c|c|c|c|}
\hline \multirow[t]{2}{*}{ Parameter } & \multicolumn{2}{|c|}{$\amalg_{\text {Vertical } ـ}$} & \multirow[t]{2}{*}{ Lagoon scale } & \multicolumn{3}{|c|}{$\ldots$ Temporal variation } & \multirow[t]{2}{*}{$\mathrm{n}$} \\
\hline & Day-night & Day-to-day & & Day-night & Day-to-day & Seasonal & \\
\hline Wind direction & - & - & - & $9^{\mathrm{b}}$ & $29^{\mathrm{a}}$ & 9 & $6,4,1$ \\
\hline Wind velocity & - & - & - & $22^{\mathrm{a}}$ & $32^{\mathrm{a}}$ & 19 & $6,4,1$ \\
\hline Temperature & $0.13^{\mathrm{b}}$ & $0.16^{\mathrm{b}}$ & $0.35^{\mathrm{a}}$ & $0.12^{\mathrm{b}}$ & $0.45^{\mathrm{a}}$ & 3.11 & $42,1080,88,6,48,1$ \\
\hline Salinity & $0.07^{\mathrm{ab}}$ & $0.05^{\mathrm{b}}$ & $0.40^{\mathrm{a}}$ & $0.04^{\mathrm{b}}$ & $0.44^{\mathrm{a}}$ & 0.30 & $42,1080,88,6,48,1$ \\
\hline \multicolumn{8}{|l|}{ In vivo $\mathrm{chl} a$} \\
\hline Water column & $27^{\mathrm{b}}$ & $38^{\mathrm{a}}$ & $23^{\mathrm{ab}}$ & $24^{\mathrm{ab}}$ & $25^{\mathrm{b}}$ & 25 & $42,1080,88,6,48,1$ \\
\hline By $10 \mathrm{~m}$ depth layers & - & - & $30^{\mathrm{a}}$ & $26^{\mathrm{a}}$ & $32^{\mathrm{a}}$ & 24 & $440,30,223,5$ \\
\hline Chl $a<2 \mu \mathrm{m}$ & $24^{\mathrm{bc}}$ & - & $27^{\mathrm{b}}$ & $18^{\mathrm{c}}$ & $32^{\mathrm{a}}$ & 18 & $34,46,24,48,1$ \\
\hline Chl $a>2 \mu \mathrm{m}$ & $34^{\mathrm{a}}$ & - & $43^{\mathrm{a}}$ & $30^{\mathrm{a}}$ & $47^{a}$ & 3 & $34,46,24,48,1$ \\
\hline Nanophytoplankton & $35^{\mathrm{b}}$ & - & $35^{\mathrm{ab}}$ & $35^{\mathrm{ab}}$ & $46^{\mathrm{a}}$ & 32 & $41,25,29,48,1$ \\
\hline Prochlorococcus & $23^{b}$ & - & $37^{a}$ & $28^{\mathrm{ab}}$ & $36^{\mathrm{a}}$ & 31 & $41,25,29,48,1$ \\
\hline Picoeukayotes & $18^{\mathrm{b}}$ & - & $30^{\mathrm{a}}$ & $24^{\mathrm{a}}$ & $27^{\mathrm{a}}$ & 21 & $41,25,29,48,1$ \\
\hline Synechococcus & $20^{\mathrm{b}}$ & - & $36^{\mathrm{a}}$ & $30^{\mathrm{a}}$ & $31^{\mathrm{a}}$ & 21 & $41,25,29,48,1$ \\
\hline LNA bacteria & $37^{\mathrm{a}}$ & - & $32^{\mathrm{a}}$ & $46^{\mathrm{a}}$ & $38^{\mathrm{a}}$ & 37 & $41,25,29,48,1$ \\
\hline HNA bacteria & $44^{\mathrm{a}}$ & - & $40^{\mathrm{a}}$ & $55^{\mathrm{a}}$ & $42^{\mathrm{a}}$ & 81 & $41,25,29,48,1$ \\
\hline
\end{tabular}



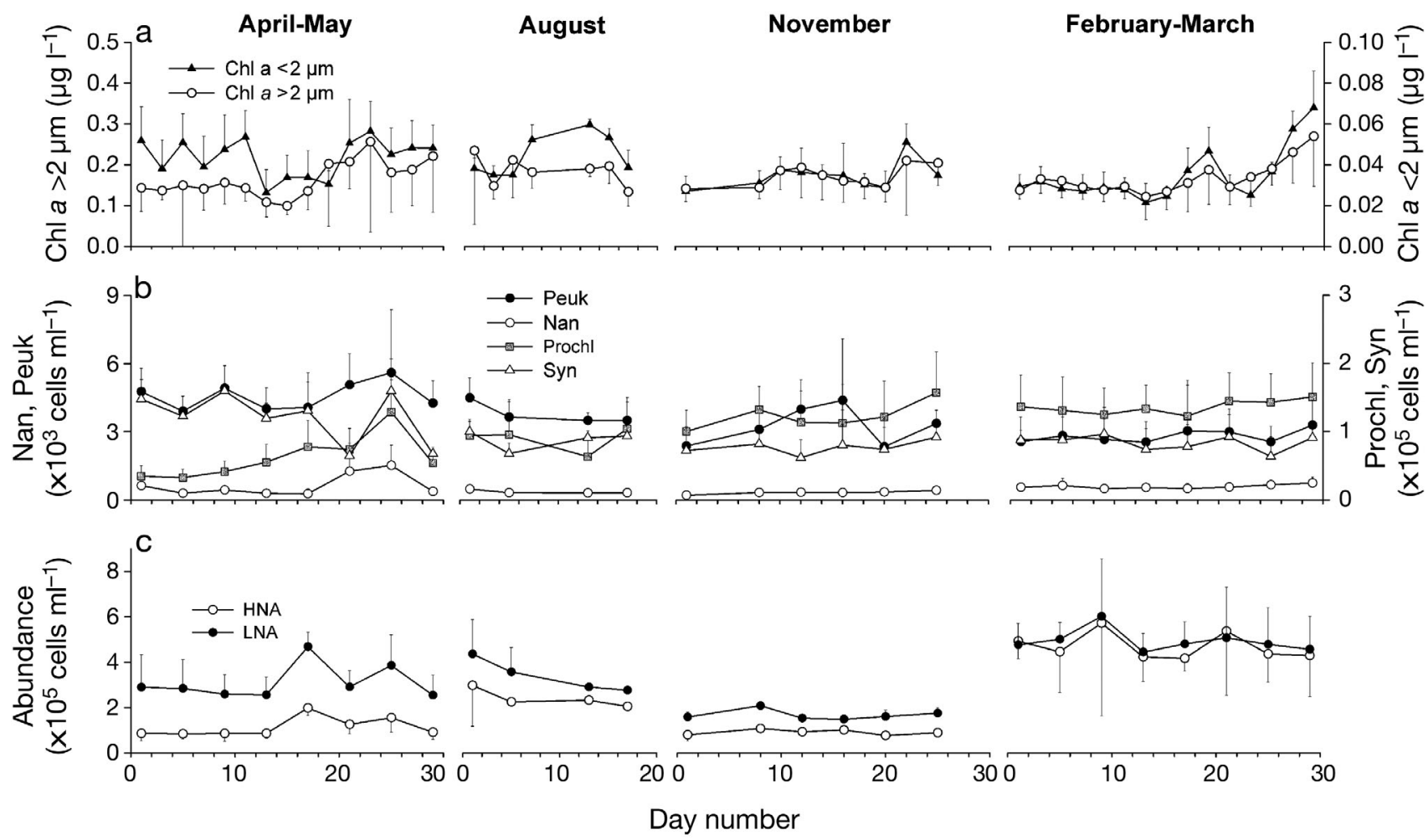

Fig. 5. Day-to-day variation in the (a) concentrations of chl $a>2 \mu \mathrm{m}$ (left scale) and $<2 \mu \mathrm{m}$ (right scale), (b) abundances of nanophytoplankton (Nan) \& picoeukaryotes (Peuk) (left scale) and Prochlorococcus (Prochl) \& Synechococcus (Syn) (right scale), and (c) abundances of high-nucleic acid (HNA) \& low-nucleic acid (LNA) bacteria at $5 \mathrm{~m}$ depth during the 4 surveys (April-May 2007, August 2007, November 2007 and February-March 2008). Data are means ( \pm SD) of measurements at the 12 lagoon stations

\section{Seasonal variability}

Mean data based on the day-to-day studies during the 4 surveys are summarized in Table 4 . The highest wind velocities were measured in July-August $(27.3 \pm$ $\left.7.6 \mathrm{~km} \mathrm{~h}^{-1}\right)$, with a general east-southeast trend $(100 \pm$ $24^{\circ}$ ). The lowest wind velocity was recorded in November $\left(16.7 \pm 7.0 \mathrm{~km} \mathrm{~h}^{-1}\right)$, with a general dirction of 113.7 $\pm 58.2^{\circ}$. The April-May and July-August surveys appeared to be the warmest and coldest periods with

Table 4. Seasonal variations in the meteorological, hydrological and hydrobiological parameters. Data are averages $( \pm$ SDs) from the day-to-day study at the 12 lagoon stations. Different superscript letters indicate significant differences among surveys (Tukey's test, $\mathrm{p}<0.05$ ). Temperature, salinity and in vivo chl a data are water column averages, other data are measurements made at $5 \mathrm{~m}$ depth. HNA: high-nucleic acid, LNA: low-nucleic acid

\begin{tabular}{|lccccc|}
\hline Parameter & April-May 07 & July-Aug 07 & November 07 & Feb-March 08 \\
\hline Wind direction $\left({ }^{\circ}\right)$ & $93.9 \pm 16 .^{\mathrm{a}}$ & $100.0 \pm 24.0^{\mathrm{ab}}$ & $113.7 \pm 58.2^{\mathrm{b}}$ & $96.6 \pm 20.5^{\mathrm{ab}}$ & $29,15,20,29$ \\
Wind velocity $\left(\mathrm{km} \mathrm{h}^{-1}\right)$ & $21.7 \pm 6.5^{\mathrm{a}}$ & $27.3 \pm 7.6^{\mathrm{b}}$ & $16.7 \pm 7.0^{\mathrm{c}}$ & $20.0 \pm 1.0^{\mathrm{ac}}$ & $29,15,20,29$ \\
Water temperature $\left({ }^{\circ} \mathrm{C}\right)$ & $29.31 \pm 0.15^{\mathrm{a}}$ & $27.19 \pm 0.09^{\mathrm{b}}$ & $28.22 \pm 0.09^{\mathrm{c}}$ & $28.56 \pm 0.13^{\mathrm{d}}$ & $>10^{3}$ \\
Salinity & $36.23 \pm 0.27^{\mathrm{a}}$ & $36.39 \pm 0.01^{\mathrm{b}}$ & $36.22 \pm 0.02^{\mathrm{ac}}$ & $36.14 \pm 0.02^{\mathrm{c}}$ & $>10^{3}$ \\
In vivo chl a $\left(\mu \mathrm{u} \mathrm{l}^{-1}\right)$ & $0.41 \pm 0.07^{\mathrm{a}}$ & $0.30 \pm 0.04^{\mathrm{b}}$ & $0.26 \pm 0.04^{\mathrm{c}}$ & $0.25 \pm 0.07^{\mathrm{c}}$ & $>10^{3}$ \\
Chl a $<2 \mu \mathrm{m}\left(\mu \mathrm{g} \mathrm{l}^{-1}\right)$ & $0.22 \pm 0.08^{\mathrm{a}}$ & $0.19 \pm 0.05^{\mathrm{b}}$ & $0.15 \pm 0.05^{\mathrm{c}}$ & $0.17 \pm 0.08^{\mathrm{d}}$ & $180,76,120,180$ \\
Chl a $>2 \mu \mathrm{m}\left(\mu \mathrm{g} \mathrm{l}^{-1}\right)$ & $0.03 \pm 0.03^{\mathrm{a}}$ & $0.03 \pm 0.02^{\mathrm{a}}$ & $0.03 \pm 0.01^{\mathrm{a}}$ & $0.03 \pm 0.01^{\mathrm{a}}$ & $180,76,120,180$ \\
Nanophytoplankton $\left(10^{3} \mathrm{ml}^{-1}\right)$ & $0.65 \pm 0.59^{\mathrm{a}}$ & $0.37 \pm 0.14^{\mathrm{b}}$ & $0.33 \pm 0.14^{\mathrm{b}}$ & $0.59 \pm 0.22^{\mathrm{a}}$ & $95,40,72,96$ \\
Prochlorococcus $\left(10^{3} \mathrm{ml}^{-1}\right)$ & $63 \pm 40^{\mathrm{a}}$ & $95 \pm 38^{\mathrm{b}}$ & $123 \pm 50^{\mathrm{c}}$ & $136 \pm 44^{\text {cd }}$ & $95,40,72,96$ \\
Picoeukayotes $\left(10^{3} \mathrm{ml}^{-1}\right)$ & $4.58 \pm 1.45^{\mathrm{a}}$ & $3.84 \pm 0.94^{\mathrm{b}}$ & $3.26 \pm 1.51^{\mathrm{c}}$ & $2.81 \pm 1.09^{\mathrm{d}}$ & $95,40,72,96$ \\
Synechococcus $\left(10^{3} \mathrm{ml}^{-1}\right)$ & $122 \pm 48^{\mathrm{a}}$ & $88 \pm 20^{\mathrm{ab}}$ & $77 \pm 39^{\mathrm{b}}$ & $84 \pm 36^{\mathrm{b}}$ & $95,40,72,96$ \\
LNA bacteria $\left(10^{3} \mathrm{ml}^{-1}\right)$ & $312 \pm 123^{\mathrm{a}}$ & $229 \pm 144^{\mathrm{b}}$ & $168 \pm 29^{\mathrm{c}}$ & $403 \pm 191^{\mathrm{d}}$ & $95,40,72,96$ \\
HNA bacteria $\left(10^{3} \mathrm{ml}^{-1}\right)$ & $115 \pm 54^{\mathrm{a}}$ & $96 \pm 127^{\mathrm{b}}$ & $92 \pm 20^{\mathrm{c}}$ & $373 \pm 254^{\mathrm{b}}$ & $95,40,72,96$ \\
\hline
\end{tabular}



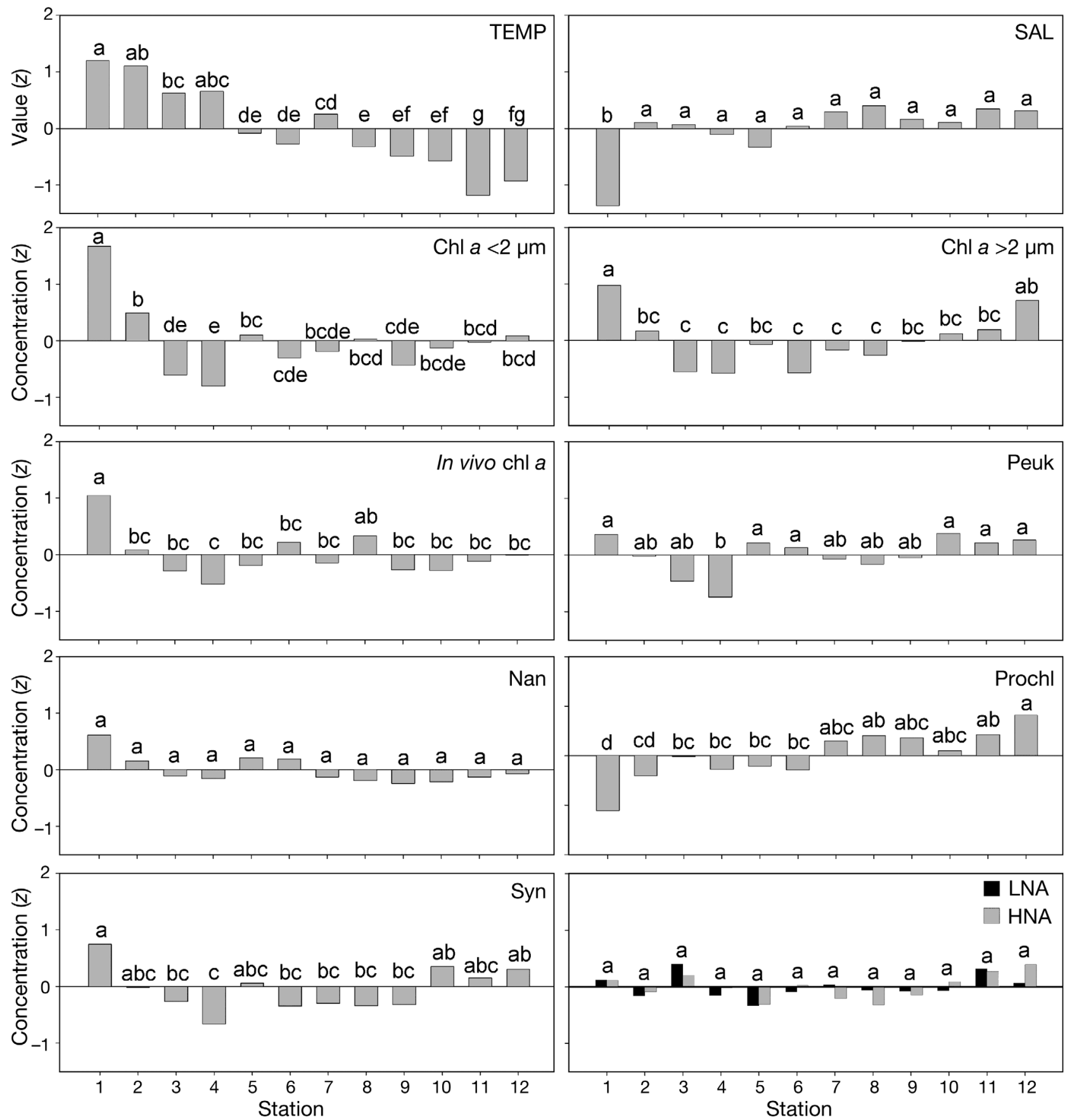

Fig. 6. Lagoon scale variation in the standard score $z$ of temperature (TEMP), salinity (SAL) and in vivo chl a averaged over the whole water column, and chl $a<2 \mu \mathrm{m}$, chl $a>2 \mu \mathrm{m}$, nanophytoplankton (Nan), picoeukaryote (Peuk), Prochlorococcus (Prochl), Synechococcus (Syn), high-nucleic acid (HNA) and low-nucleic acid (LNA) bacterial concentrations at $5 \mathrm{~m}$ depth. Data are from all day-to-day studies. Different letters indicate significant differences among stations (Tukey's test, $\mathrm{p}<0.05$ )

respective temperatures of $29.31 \pm 0.15$ and $27.19 \pm$ $0.09^{\circ} \mathrm{C}$. Finally, the highest and lowest salinities were recorded in July-August and in February-March (36.39 \pm 0.01 and $36.14 \pm 0.02$, respectively).

The seasonal $\mathrm{CV}$ of the in vivo chl a averaged over the water column was $25 \%$, with a general decrease from $0.41 \pm 0.07 \mathrm{ug} \mathrm{l}^{-1}$ in April-May to $0.25 \pm 0.07 \mu \mathrm{g}$ $\mathrm{l}^{-1}$ in Feb-March. Chl $a<2 \mu \mathrm{m}$ extracted at $5 \mathrm{~m}$ depth showed a lower CV of $18 \%$ and a different trend, with a maximum concentration of $0.22 \pm 0.08 \mu \mathrm{g} \mathrm{l}^{-1}$ in April-May and a minimum of $0.15 \pm 0.05 \mu \mathrm{g} \mathrm{l}^{-1}$ in November. No significant seasonal variation $(p>0.05)$ was found in chl $a>2 \mu \mathrm{m}$. The annual trend for Nan showed the highest abundances of $0.65 \times 10^{3} \pm$ 
$0.59 \times 10^{3}$ and $0.59 \times 10^{3} \pm 0.22 \times 10^{3} \mathrm{ml}^{-1}$ in April-May and Feb-March ( $\mathrm{p}<0.05)$, respectively. Prochl showed a significant increase in mean abundance $(\mathrm{p}<0.05)$ from the first to the last survey $\left(63 \times 10^{3} \pm 40 \times 10^{3}\right.$ and $136 \times 10^{3} \pm 44 \times 10^{3} \mathrm{ml}^{-1}$ in April-May and Feb-March, respectively). The highest Syn abundances of $122 \times 10^{3}$ $\pm 48 \times 10^{3} \mathrm{ml}^{-1}$ were measured during the first survey. Mean Peuk abundances decreased from the first to the last survey, with values of $4.58 \times 10^{3} \pm 1.45 \times 10^{3}$ and $2.81 \times 10^{3} \pm 1.09 \times 10^{3} \mathrm{ml}^{-1}$ in April-May and Feb-March, respectively. The HNA proportion represented 27, 30 and $35 \%$ of the total bacterial concentration during the first 3 surveys, and attained a contribution of $48 \%$ in Feb-March. LNA bacteria showed a seasonal trend in abundance, with minimum values during surveys at lower temperature and maximum values of $403 \times 10^{3} \pm 191 \times 10^{3} \mathrm{ml}^{-1}$ in Feb-March. HNA bacteria showed a seasonal CV of $81 \%$ (Table 3 ), which was mostly due to a marked increase in abundance in Feb-March $\left(373 \times 10^{3} \pm 264 \times 10^{3} \mathrm{ml}^{-1}\right)$.

\section{DISCUSSION}

\section{Hydrobiological state of the Ahe Lagoon}

The phytoplankton composition reported in this study, with $83 \%$ of chl a extracted from picoplankton communities being dominated in terms of abundance by Synechococcus and Prochlorococcus, was in the range of previous surveys in tropical lagoons (Charpy et al. 1992, Ferrier-Pagès \& Furla 2001). However, picophytoplankton abundances appeared to be higher than mean levels generally found on Polynesian atolls, the mean Prochl, Syn and Peuk abundances observed in Ahe being 1.7-, 1.3- and 3.2-fold higher, respectively, than mean values found in the 11 atoll lagoons investigated by Charpy \& Blanchot (1998). Thus, Ahe seems to be comparable to closed atolls like Takapoto or Taiaro, mainly because of its high abundance of Peuk (Charpy \& Blanchot 1998). Despite exchanges with the surrounding ocean through the pass and reef-flat spillways, the depth of the lagoon could contribute to the decrease in water exchanges and thus to the increase in phytoplankton concentration, especially of lagoonal communities like picoeukaryotes (Charpy et al. 1997, Pagès et al. 2001).

Very few data on autotrophic nanoplankton in atoll lagoons are available (González et al. 1998). Nonetheless, our day-to-day abundances, which ranged between $0.12 \times 10^{3}$ and $2.87 \times 10^{3} \mathrm{ml}^{-1}$, are equivalent to the $0.2 \times 10^{3}$ to $1.1 \times 10^{3} \mathrm{ml}^{-1}$ measured during day-today surveys in the Tikehau Atoll lagoon (González et al. 1998), and are lower than data reported by FerrierPagès \& Furla (2001) $\left(2.1 \times 10^{3}\right.$ to $5.5 \times 10^{3} \mathrm{ml}^{-1}$, measured in the 2 largest Polynesian atolls).
For the bacterial population, total bacterial abundances (HNA + LNA) from our day-to-day studies were between $0.16 \times 10^{6}$ and $3.66 \times 10^{6} \mathrm{ml}^{-1}$, which is in the same range as values previously recorded in the Tikehau Atoll lagoon: $1.2 \times 10^{6}$ to $2.6 \times 10^{6} \mathrm{ml}^{-1}$ (Torréton \& Dufour 1996) and $1.52 \times 10^{6} \mathrm{ml}^{-1}$ (González et al. 1998).

\section{Spatio-temporal scales of variability}

During this study, both spatial and temporal fluctuations in the studied microbial communities were measured. Based on the mean CV analysis (Table 3), phyto- and bacterioplankton descriptors display large variations $>20 \%$ in most cases. As reported by González et al. (1998) for the microbial communities of Tikehau Lagoon, day-to-day fluctuations also represented a major source of temporal variability in our study. These variations also appear to be closely related to the vertical structure and dynamics of phytoplankton communities, with increases recorded in the surface layer mostly originating from deeper layers. With a mean depth of $50 \mathrm{~m}$, Ahe is a very deep atoll lagoon compared with the mean depth of $25 \mathrm{~m}$ found across 28 Polynesian atoll lagoons by Pagès \& Andréfouët (2001). During our surveys, the deep layer appeared to be more productive than the upper layer and reached consistently higher phytoplankton concentrations. This pattern was detected on a day-night scale, showing transitory vertical gradients, and through long-term events that were recorded during day-to-day measurements. Vertical gradients in phytoplankton that were recorded in this study also appeared to be 2 to $3 \times$ higher than transitory gradients that were previously described during day-to-day measurements in shallow atoll lagoons (Charpy 1996a, Charpy \& Blanchot 1998, Buestel \& Pouvreau 2000).

At the same time that this variation was shown on small spatio-temporal scales, phytoplankton abundance and composition also showed a patchy spatial configuration at the lagoon scale. Large-scale patterns based on several day-to-day samplings appeared to be stable between surveys and specific to the different communities, as distribution in lagoonal communities (i.e. Peuk, Syn) was different from that in the oceanic community (i.e. Prochl). Only Nan and bacteria appeared to be homogeneously distributed over the lagoon.

No clear seasonality of phytoplankton abundance in atoll lagoons has been reported in the literature. Some studies describe annual variability in total chl a concentration without clear seasonality (Charpy 1996a), while others report marked seasonality, with the highest phytoplankton concentration being observed during the austral summer (Buestel \& Pouvreau 2000). In Ahe, pico- and nanophytoplankton were characterized 
by higher Nan, Syn and bacterial abundances during the warm periods. Such a pattern was not seen for Peuk and Prochl communities. These results appear to differ from the seasonal variations in picoplankton community structure observed in the subtropical North Pacific Ocean, where the abundance of Prochl typically peaks in summer, Syn in winter and Peuk in spring (Campbell et al. 1997). In addition, the bacterial abundance seasonality observed during our study appeared to be more similar to the observations of Moriarty et al. (1985) on the Great Barrier Reef than observations from the Tikehau Lagoon, where no seasonal trend was detected (Torréton \& Dufour 1996). To our knowledge, data on nanophytoplankton seasonality in atoll lagoons are very scarce. However, Charpy (1996a) reported the same seasonal pattern in the concentration of chl $a>3 \mu \mathrm{m}$ in the Tikehau Lagoon as that of Nan in our study, with the highest concentrations being observed in the austral summer. However, our surveys covered only 1 yr and sampling over several years would be necessary to obtain a reliable description of seasonal patterns.

\section{Factors driving variability}

Wind appeared to be the main factor driving the environmental heterogeneity recorded during our surveys. Wind provides the forcing factor that drives vertical structures. No significant relation was found between wind speed and bacterial abundance (data not shown); release of bottom communities by the resuspension process, as reported by Torréton \& Dufour (1996) in the Tikehau Lagoon, thus appeared to be limited in our case, probably due to the depth of the Ahe Lagoon.

No significant relation was found between daynight microbial abundance variation and tide or wind (Table 2). Light appeared to be the main factor that was directly or indirectly driving day-night variations. As reported by Vaulot \& Marie (1999) in the equatorial Pacific, the vertical structure of Prochlorococcus and Synechococcus should be related to photoinhibition in the upper layers and to an increase in chlorophyll synthesis from the surface to the bottom. This photoinhibition could also explain the time shift in fluorescence increase that was observed in the upper $10 \mathrm{~m}$ during day-night cycles (Dandonneau \& Neveux 1997). In addition, phytoplankton production appeared to be highly limited by nutrient supply in atoll lagoons (Dufour \& Berland 1999, Ferrier-Pagès \& Furla 2001). Indeed, nutrients that are commonly measured in atoll lagoons showed very low concentrations, with relative nitrogen or phosphorus limitation being linked to atoll morphometry (Dufour et al. 2001). Nutrient concentra- tions are controlled by water exchange with the ocean, uptake by primary producers and recycling processes. Nutrient concentrations are high in atoll lagoon sediment pore water (Charpy-Roubaud et al. 1996), and nutrient fluxes at the sediment-water interface can increase phytoplankton growth close to the bottom. A bottom effect providing more favourable nutrient conditions by organic matter remineralization (Charpy et al. 1997) thus appeared to be a potential factor allowing phytoplankton growth in the deep layers.

At the lagoon scale, the kind of patchy structure observed has been previously described in the Takapoto Lagoon, with rich sectors being related to longer water residence time, accumulation by the northeast wind and potential anthropogenic enrichment (Sournia \& Ricard 1976, Delesalle et al. 2001). In our study, the patchy phytoplankton structure appeared to be closely linked to the geomorphology of the rim, lagoon depth and the proximity of the pass. The 2 sectors showing a typical lagoon signature, with high nanoplanktonic, picoeukaryotic and Synechococcus concentrations, were defined westward by shallow waters and eastward by a sector protected from the prevailing wind trend by a reef rim without reef-flat spillways, which can be linked to a retention zone. These 2 sectors were also distant from the pass and its diluting effect. As reported by Tartinville et al. (1997) for the Mururoa Atoll lagoon, it is conceivable that a large fraction of the water entering the lagoon during the rising tide remains in the neighbourhood of the pass. This hypothesis explains why only a small extent of the sector is directly influenced by the pass, with effects being mostly confined to Stns L03 and L04 that are characterized by consistently lower concentrations of lagoonal phytoplankton communities.

Concerning seasonality, Agawin et al. (1998) showed the high dependence of Syn growth rate on temperature, which in our case was around the optimum value of $28^{\circ} \mathrm{C}$ and could explain only a small part of the variability recorded (Moore et al. 1995). Prochl and Peuk showed no seasonal patterns but inverse dynamics based on the 4 surveys. Since Prochl is described as an oceanic marker and Peuk as a lagoon marker (Charpy 1996b), the increase in Prochl abundance over the 4 surveys and the inverse dynamics of Peuk could reflect an increase in oceanic influence in the Ahe Lagoon. No water flux data are available for the studied period, but flux calculations made through a modelling study for the sampling period should provide an interesting approach to understanding these long-term dynamics. Moreover, we did not measure the heterotrophic compartment dynamics, which could have a significant predation effect on bacterial and cyanobacterial populations and, therefore, also a significant effect on their spatio-temporal dynamics (González et al. 1998). 


\section{CONCLUSIONS}

The present study offers new insights into spatiotemporal variation scales in phyto- and bacterioplankton abundance in a deep atoll lagoon. CVs revealed high variability levels on every scale, with mean values exceeding $20 \%$ for all microbial communities. Nonetheless, the vertical scale appeared to be a key determinant of spatio-temporal variability in phytoplankton biomass, as estimated by in vivo chl $a$, with a vertical gradient showing an increase from the surface to the bottom. This suggests photoinhibition in the surface layers and a bottom effect providing more favourable nutrient conditions. Concurrently, high frequency sampling during these long surveys showed the primacy of day-to-day variability over other temporal scales. Wind was the main factor driving vertical and day-today variability, and allowing phytoplankton and bacterioplankton mixing from the bottom. Lastly, any direct oceanic influence appeared to be confined to the vicinity of the pass.

Acknowledgements. This study was supported by the Institut Français de Recherche pour l'Exploitation de la Mer (Ifremer) and the French Polynesian government (research delegation). We thank the Ifremer and Service de la Perliculture staff for their efficient help during sample collection; the Pa'umotu: the Maifano family and A. Bennett, for their effective assistance on Ahe Atoll; and H. McCombie for helpful comments and English revision.

\section{LITERATURE CITED}

Agawin NSR, Duarte CM, Agustí S (1998) Growth and abundance of Synechococcus sp. in a Mediterranean Bay: seasonality and relationship with temperature. Mar Ecol Prog Ser 170:45-53

Andréfouët S, Pagès J, Tartinville B (2001) Water renewal time for classification of atoll lagoons in the Tuamotu Archipelago (French Polynesia). Coral Reefs 20:399-408

Atkinson M, Smith SV, Stroup ED (1981) Circulation in Enewetak atoll lagoon. Limnol Oceanogr 26:1074-1083

Buestel D, Pouvreau S (2000) Particulate matter in Takapoto lagoon waters: potential food for cultivated pearl oysters. Oceanol Acta 23:193-210

Campbell L, Liu HB, Nolla HA, Vaulot D (1997) Annual variability of phytoplankton and bacteria in the subtropical North Pacific Ocean at Station ALOHA during the 1991-1994 ENSO event. Deep-Sea Res I 44:167-192

- Charpy L (1996a) Phytoplankton biomass and production in two Tuamotu atoll lagoons (French Polynesia). Mar Ecol Prog Ser 145:133-142

Charpy L (1996b) Phytoplankton biomass and productivity in the Great Astrolabe Lagoon. Centre ORSTOM de Tahiti, Papeete (French Polynesia)

> Charpy L, Blanchot J (1998) Photosynthetic picoplankton in French Polynesian atoll lagoons: estimation of taxa contribution to biomass and production by flow cytometry. Mar Ecol Prog Ser 162:57-70

Charpy L, Blanchot J (1999) Picophytoplankton biomass, com- munity structure and productivity in the Great Astrolabe Lagoon, Fiji. Coral Reefs 18:255-262

Charpy L, Blanchot J, Lo L (1992) Cyanobacteria Synechococcus spp. contribution to primary production in a closed atoll lagoon (Takapoto, Tuamotu, French Polynesia). CR Acad Sci III 314:395-401

Charpy L, Dufour P, Garcia N (1997) Particulate organic matter in sixteen Tuamotu atoll lagoons (French Polynesia). Mar Ecol Prog Ser 151:55-65

Charpy-Roubaud C, Charpy L, Lemasson L (1988) Benthic and planktonic primary production of an open atoll lagoon (Tikehau, French Polynesia). Proc 6th Int Coral Reef Symp, Townsville 2:551-556

Charpy-Roubaud C, Charpy L, Sarazin G (1996) Diffusional nutrient fluxes at the sediment-water interface and organic matter mineralization in an atoll lagoon (Tikehau, Tuamotu Archipelago, French Polynesia). Mar Ecol Prog Ser 132:181-190

Cho BC, Azam F (1990) Biogeochemical significance of bacterial biomass in the ocean's euphotic zone. Mar Ecol Prog Ser 63:253-259

> Dandonneau Y, Neveux J (1997) Diel variations of in vivo fluorescence in the eastern equatorial Pacific: an unvarying pattern. Deep-Sea Res I 44:1869-1880

$>$ Delesalle B, Sournia A (1992) Residence time of water and phytoplankton biomass in coral reef lagoons. Cont Shelf Res 12:939-949

Delesalle B, Sakka A, Legendre L, Pagès J, Charpy L, Loret P (2001) The phytoplankton of Takapoto Atoll (Tuamotu Archipelago, French Polynesia): time and space variability of biomass, primary production and composition over 24 years. Aquat Living Resour 14:175-182

Dufour P, Berland B (1999) Nutrient control of phytoplanktonic biomass in atoll lagoons and Pacific Ocean waters: studies with factorial enrichment bioassays. J Exp Mar Biol Ecol 234:147-166

Dufour P, Andréfouët S, Charpy L, Garcia N (2001) Atoll morphometry controls lagoon nutrient regime. Limnol Oceanogr 46:456-461

> Ferrier-Pagès C, Furla P (2001) Pico- and nanoplankton biomass and production in the two largest atoll lagoons of French Polynesia. Mar Ecol Prog Ser 211:63-76

> González JM, Torréton JP, Dufour P, Charpy L (1998) Temporal and spatial dynamics of the pelagic microbial food web in an atoll lagoon. Aquat Microb Ecol 16:53-64

Haury L, McGowan J, Wiebe P (1978) Patterns and processes in the time-space scales of plankton distribution. In: Steele JH (ed) Spatial pattern in plankton communities. Plenum Press, New York, p 277-327

Le Borgne R, Blanchot J, Charpy L (1989) Zooplankton of Tikehau Atoll (Tuamotu Archipelago) and its relationship to particulate matter. Mar Biol 102:341-353

Marie D, Partensky F, Simon N, Guillou L, Vaulot D (2000) Flow cytometry analysis of marine picoplankton. In: Diamond RA, DeMaggio S (eds) In living colors: protocols in flow cytometry and cell sorting. Springer Verlag, Berlin, p 422-454

Moore LR, Goericke R, Chisholm SW (1995) Comparative physiology of Synechococcus and Prochlorococcus: influence of light and temperature on growth, pigments, fluorescence and absorptive properties. Mar Ecol Prog Ser 116:259-275

> Moriarty DJW, Pollard PC, Hunt WG (1985) Temporal and spatial variation in bacterial production in the water column over a coral reef. Mar Biol 85:285-292

> Pagès J, Andréfouët S (2001) A reconnaissance approach for hydrology of atoll lagoons. Coral Reefs 20:409-414 
Pagès J, Andréfouët S, Delesalle B, Prasil V (2001) Hydrology and trophic state in Takapoto Atoll lagoon: comparison with other Tuamotu lagoons. Aquat Living Resour 14:183-193

Pomeroy LR (1974) The ocean's food web, a changing paradigm. BioScience 24:499-504

Sournia A, Ricard M (1976) Données sur l'hydrologie et la productivité du lagon d'un atoll fermé (Takapoto, Iles Tuamotu). Vie Milieu 26:243-279

Tartinville B, Deleersnijder E, Rancher J (1997) The water residence time in the Mururoa atoll lagoon: sensitivity analysis of a three-dimensional model. Coral Reefs 16:193-203

Torréton JP, Dufour P (1996) Temporal and spatial stability of bacterioplankton biomass and productivity in an atoll lagoon. Aquat Microb Ecol 11:251-261

Torréton JP, Rochelle-Newall E, Jouon A, Faure V, Jacquet S, Douillet P (2007) Correspondence between the distribu-

Editorial responsibility: Urania Christaki,

Wimereux, France tion of hydrodynamic time parameters and the distribution of biological and chemical variables in a semi-enclosed coral reef lagoon. Estuar Coast Shelf Sci 74:766-776

Troussellier M, Courties C, Zettelmaier S (1995) Flow cytometric analysis of coastal lagoon bacterioplankton and picophytoplankton: fixation and storage effects. Estuar Coast Shelf Sci 40:621-633

Vaulot D, Marie D (1999) Diel variability of photosynthetic picoplankton in the equatorial Pacific. J Geophys Res 104:3297-3310

Wasmund N, Topp I, Schories D (2006) Optimising the storage and extraction of chlorophyll samples. Oceanologia 48: $125-144$

Yentsch CS (1963) A method for the determination of phytoplankton chlorophyll and phaeophytin by fluorescence. Deep-Sea Res 10:221-231

Submitted: June 11, 2009; Accepted: October 8, 2009

Proofs received from author(s): March 19, 2010 